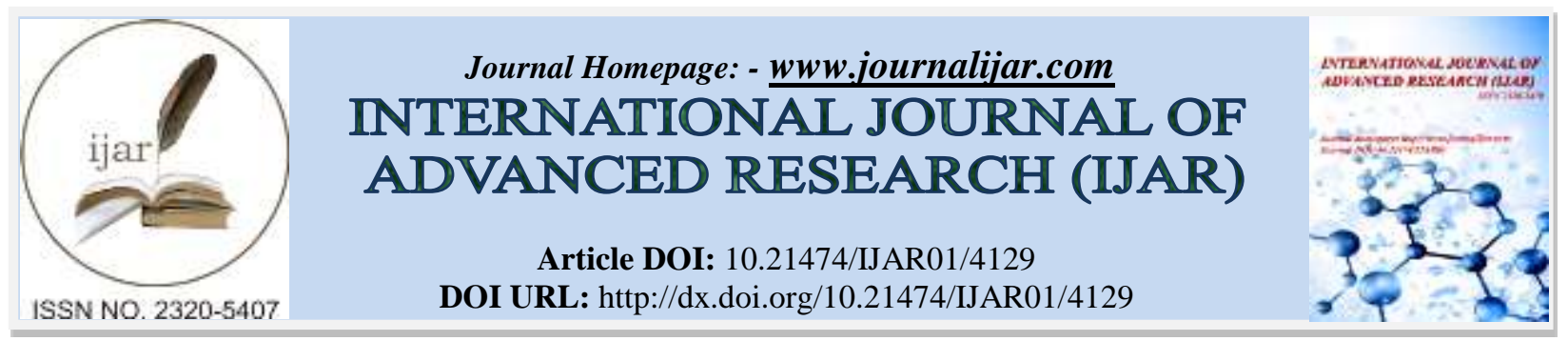

RESEARCH ARTICLE

\title{
EVALUATION ZULFI GROUND WATER QUALITY USING INDUCTIVELY COUPLED PLASMA- MASS SPECTROMETER (ICPMS).
}

\author{
N. Ibrahim*. \\ Majmaah university-Zulfi college of education.
}

\section{Manuscript Info}

Manuscript History

Received: 03 March 2017

Final Accepted: 04 April 2017

Published: May 2017

Key words:-

Heavy metals, enzymes, , toxicity, World Health Organization (WHO) Inductively Coupled Plasma-Mass Spectrometer.

\section{Abstract}

Some of the heavy metal such as Cadmium ( $\mathrm{Cd}$ ), lead ( $\mathrm{Pb})$ and Zink (Zn) etc. are strongly poisonous meals it affects the enzymes. In this study the means concentrations of Cadmium ( $\mathrm{Cd})$, lead $(\mathrm{Pb})$ and Zink ( $\mathrm{Zn})$, Aluminum ( $\mathrm{Al})$, and Chromium $(\mathrm{Cr})$ were measured using Inductively Coupled Plasma-Mass Spectrometer to find it concentrations limits prescribed by World Health Organization (WHO) for drinking water. Mean concentrations measured for all samples of Cadmium ( $\mathrm{Cd}$ ), lead ( $\mathrm{Pb})$ and Zink ( $\mathrm{Zn})$, Aluminum ( $\mathrm{Al}$ ), and Chromium $(\mathrm{Cr})$ are not exceed the drinking water specified limits prescribed by World Health Organization (WHO).

Copy Right, IJAR, 2017,. All rights reserved.

\section{Introduction:-}

water shortage Saudi Arabian has great problem because water demand is exceeding the sustainable yields of natural resources. The only reliable water resources used for municipal are desalinated water and brackish groundwater.[1].

Zulfi is considered to have a desert climate.[2]

The total population in 2017 was 32.613731 million[3] Fig.1 of which 76 percent were Saudi nationals. Some 80 percent live in the towns and cities. Between 2000 and 2005 the annual population growth rate was 2.7 percent. In 2006, 97 percent of the urban population had access to improved water sources and the whole urban population had access to improved sanitation. The agriculture sector used about $70 \%-80 \%$ from fresh water $[4,5]$. Groundwater quality is most important for drinking water or in domestic, and irrigations; its quality affected by different factors such as geochemical processes, and human activities5 . polluted Water is threats human health and economic development $[6,7,8]$. The key tool to estimate the water quality and its suitability for drinking, irrigation, or domestic is the Physical and chemical properties of groundwater[ 9, 10]. Groundwater is an important source of acceptable water for drinking the Saudi Arabia where it is the sole water source for drinking, also used in irrigation.

seasonal rainfall through surroundings, mountains as well as valleys Zulfi province is located at the bottom of a valley between two huge dunes of special composition red sand. The surrounding mountains of this valley play major role of replacing water of groundwater [11]

A heavy metals like heavy metal such as Cadmium ( $\mathrm{Cd}$ ), lead ( $\mathrm{Pb}$ ) and Zink ( $\mathrm{Zn}$ ) etc. ,are useful metals, e.g. Cobalt is used to treat anemia with pregnant woman [12], however, in high concentrations it became very dangerous to health.[17]. The health hazard of this elements is as such : 


\section{Cadmium cause:-}

kidney dysfunction hypertension and cancer, while lead cause nerves system disorder, and Chromium cause skin ulceration . the excess zinc can be cause Zinc toxicity [17] $[12,13,14]$

The main objectives of study is to estimate the water quality and its suitability for drinking, irrigation, in Zulfi province.

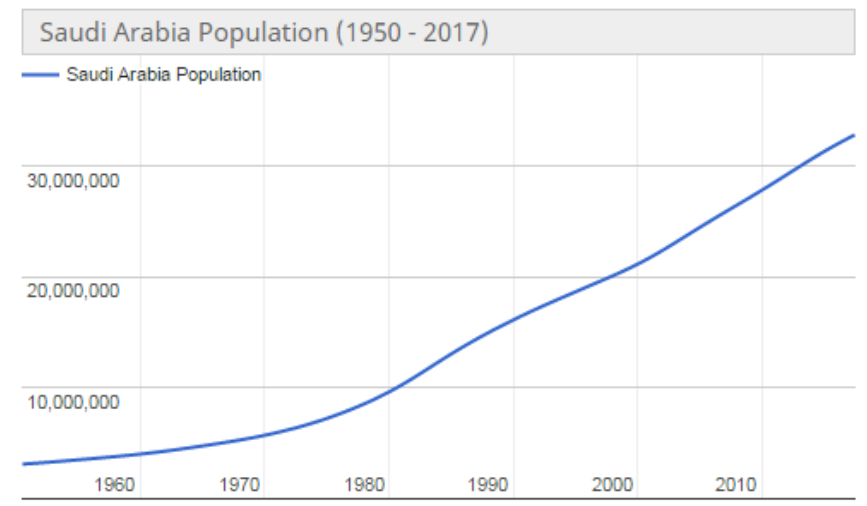

Figure 1:- progressing in Saudi Arabia population(1950-2017)[3]

\section{Materials and methods:-}

Study Area:-

Study Area: Ground water samples were collected from wells $(n=10)$ located in the Zulfi province . The Zulfi province about 260 kilometres northwest of Riyadh.[15] lies in the northern-central region of the Najd and to the south of the sheayb samnan (samnan Valley), which is the longest valley on the zulfi. It is surrounded by sand dunes to its north and west, which are known locally as the Al-Thoyr Sands. The Al-sabalh Woods are located to the north of the city.Fig 2. The sampling was carried out over four month period in 2015 . The location of the wells was recorded using Geological Positioning System (GPS).

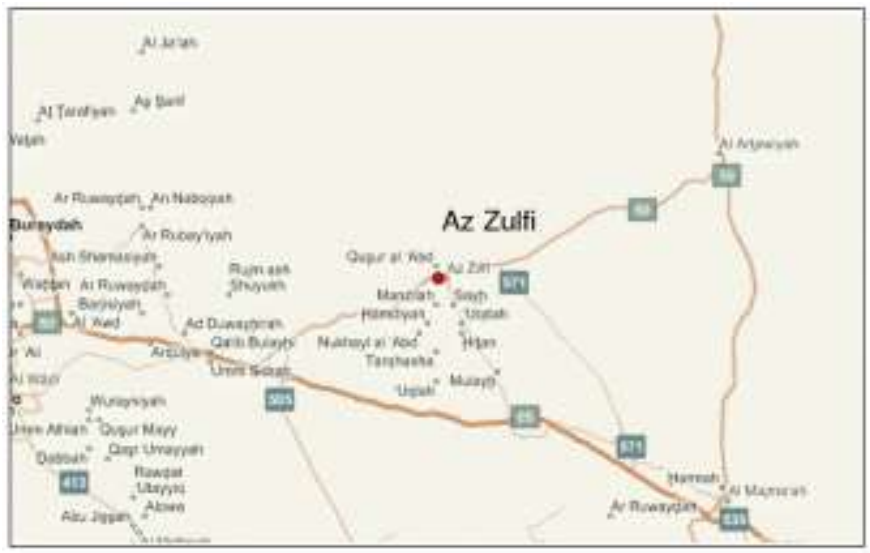

Figure(2):- Location of Zulfi province

\section{Samples collection:-}

The samples were collected in 0.25 -liter plastic bottles, These were immediately acidified to $\mathrm{pH} 2$ with HNO in order to keep metals in solution and prevent All samples were transported to the laboratory in iceboxes and refrigerated at $4{ }^{\circ} \mathrm{C}$ until analyzed.The analytical determination of trace metals was carried out by ICP-MS (Inductively Coupled Plasma-Mass Spectrometer): NexION 300D (Perkin Elmer, USA). 


\section{Results and discussion:-}

The acceptable limits of concentrations of heavy elements are shown in Table 1. [12, 16, 18,22$]$

Table 1:-The prescribed limits of heavy elements

\begin{tabular}{|l|l|l|}
\hline Metal & Highest desirable concentrations $\mathrm{mg} / \mathrm{L}$ & Maximum permissible concentrations $\mathrm{mg} / \mathrm{L}$ \\
\hline $\mathrm{Cd}$ & 75 & 200 \\
\hline $\mathrm{Al}$ & 0.03 & 0.2 \\
\hline $\mathrm{Zn}$ & 5 & 15 \\
\hline $\mathrm{Cr}$ & 0.05 & 0.05 \\
\hline $\mathrm{Pb}$ & 0.1 & 13.4 \\
\hline
\end{tabular}

Aluminum (Al) Concentration in Water Samples $(\mu \mathrm{g} / \mathrm{L})$ :-

Fig.4 The mean concentrations of ( $\mathrm{Al})$, maximum and minimum concentrations of concentrations are $0,005 \mathrm{mg} / \mathrm{L}$ and $0.00198 \mathrm{mg} / \mathrm{L}$ respectively. Table 2 .and Fig.4.The World Health Organization has recommended that aluminum levels in community water supplies should not exceed $0.2 \mathrm{mg} / \mathrm{L}$. [19].

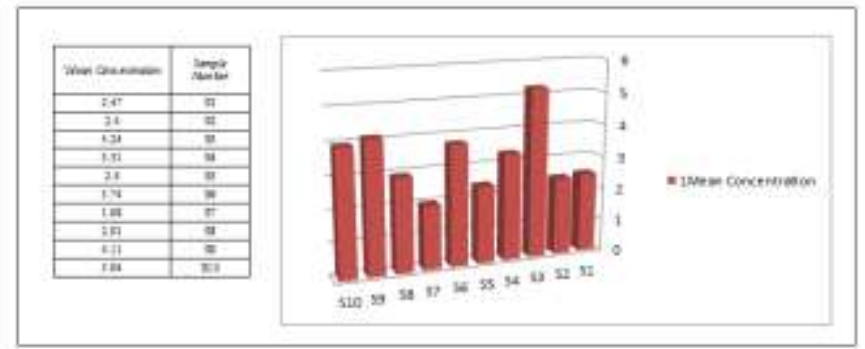

Figure 3:- Aluminum (Al) Concentration in Water Samples $(\mu \mathrm{g} / \mathrm{L})$

\section{Cadmium (Cd) Concentration in Water Samples:-}

In natural water the Permissible Cadmium concentrations are usually below $1 \mu \mathrm{g} /[[20,21]$. the concentrations of Cadmium in Zulfi ground water as measured is $0.34 \mu \mathrm{g} / \mathrm{l}$ as maximum concentration and $0.01 \mu \mathrm{g} / \mathrm{las}$ minimum concentration .Fig.4

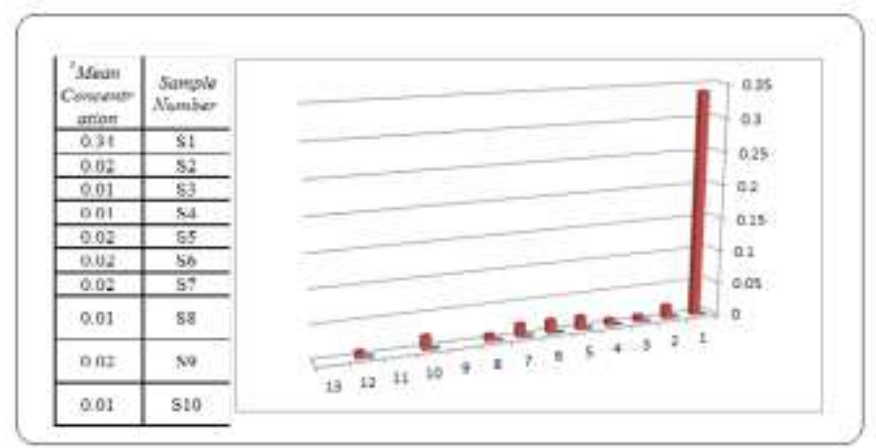

Figure 4:- Cadmium (Cd) Concentration in Water Samples $(\mu \mathrm{g} / \mathrm{L})$

\section{Lead $(\mathbf{P b})$ Concentration in Water Samples:-}

The source of lead in the environment is combustion of gasoline with lead. In environmental fund as ions $\mathrm{Pb} 2+$. it harm soft tissues is one month, and of liver is 50 years [22, 23]. Maximum permissible limit for lead in drinking water is $0.01 \mathrm{mg} / \mathrm{l}$ [24]. Maximum and minimum concentrations of $\mathrm{Pb}$ was $0.52 \mu \mathrm{g} / \mathrm{L}$ and $0.1 \mu \mathrm{g} / \mathrm{L}$ respectively Fig.5. 


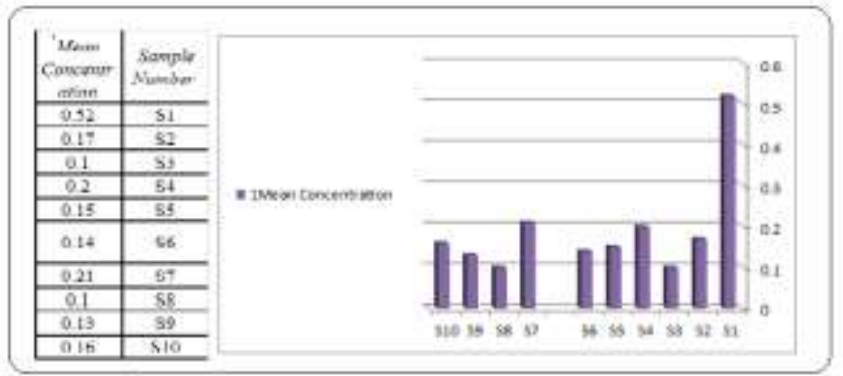

Figure 5:- Lead $(\mathrm{Pb})$ Concentration in Water Samples

Chromium (Cr) Concentration in Water Samples:-

It reviewed, that maximum acceptable concentration of with chromium in drinking water is $0.1 \mathrm{mg} / \mathrm{L}$ (100 $\mu \mathrm{g} / \mathrm{L}$ ).[25].Chromium (Cr) Concentration is acceptable for drinking $\mathrm{n}$ Zulfi ground water Fig.(6) .

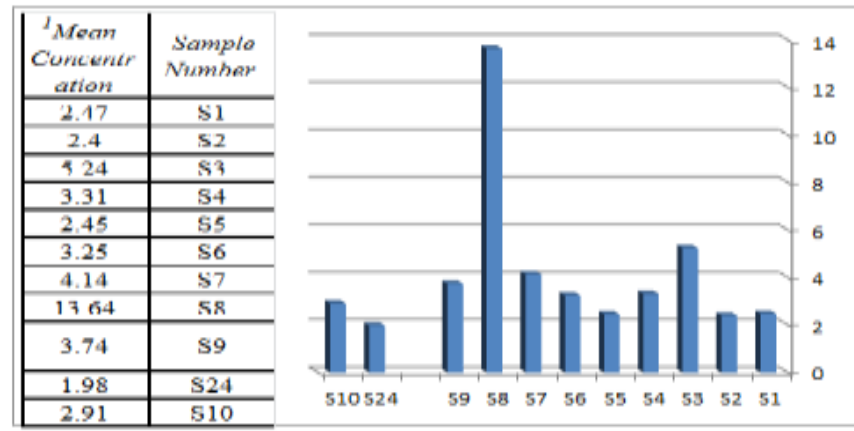

Figure 6:- Chromium $(\mathrm{Cr})$ Concentration in Water Samples $(\mu \mathrm{g} / \mathrm{L})$

Zinc (Zn) Concentration in Water Samples:

ground water will be polluted if the Concentration of $\mathrm{Zn}$ is greater than5.0 $\mathrm{mg} / \mathrm{l}[26]$. No samples exceed the permissibly value Fig.(7)

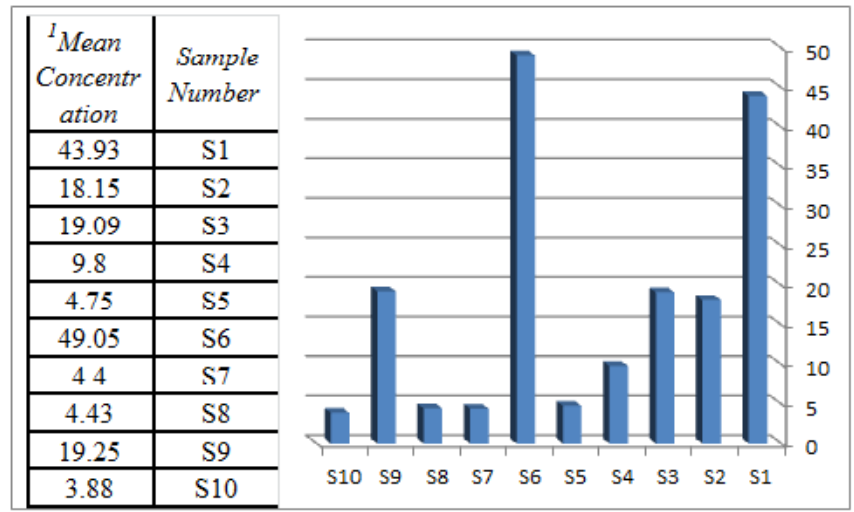

Figure 7:- Zinc (Zn)Concentration in Water Samples $(\mu \mathrm{g} / \mathrm{L})$

\section{Conclusion:-}

The main goal of this study was evaluate the groundwater quality of Zulfi province for drinking . The study indicates that the concentrations of the samples of wells and springs samples in Zulfi province below acceptable for drinking. 


\section{Acknowledgment:-}

The authors are grateful to Majmaah university Engineering and Applied Sciences Research Center for supporting this research. And great thanks to King Saud University especially to Mr. Kamal O. at for providing the support to complete this work.

\section{References:-}

1. World Environment 2013, 3(2): 66-70 DOI: 10.5923/j.env.20130302.05User Financing via Micro finance Institutions (MFI) and Utility Bills.AEI Workshop June 2009.

2. https://en.climate-data.org.

3. Elaboration of data by United Nations, Department of Economic and Social Affairs, Population Division. World Population Prospects: The 2015 Revision

4. Int J Environ Res Public Health. 2015 Oct 5;12(10):12391-411.

5. Armon, R., and J. Kitty, The Health Dimension of Groundwater Contamination. In: Groundwater Contamination and Control, Holler (Ed.). Marcel Dekker, Inc., New York, USA (1994)

6. Milovanovic, M., "Water quality assessment and determination of pollution sources along the Axios/Vardar River, Southeastern Europe.” Desalination 213 : 159-173 (2007).

7. Al-Rajab A.J., and O. Hakami, "Bahavior of the non-selective herbicide glyphosate in agricultural soil. " American Journalof Environmental Science 10(2): 94-101 (2014).

8. ALHABABY \& AL-RAJAB, Curr. World Environ., Vol. 10(1), 22-28 (2015)

9. Subba, R.N., "Seasonal variation of groundwater quality in a part of Guntur District, Andhra Pradesh, India." Environmental Geology 49: 413-429 (2006).

10. Edmunds, W.M., J.J. Carrillo-Rivera, and A. Cardona, "Geochemical evolution of groundwater beneath Mexico City." Journal of Hydrology 258 : 1-24 (2002).

11. Arab Journal of Nuclear Science and Applications, 48(3), (34-46) 2015

12. Water and Healthisbn978-81-322-1029-0

13. Toxicity, mechanism and health effects of some heavy metalsInterdiscip Toxicol. 2014 Jun; 7(2): 60-72.

14. Ground-Water Remediation Technologies Analysis Center Cynthia R. Evanko, Ph. D. and David A. Dzombak, Ph. D., P.E. Carnegie Mellon University Department of Civil and Environmental Engineering Pittsburgh, PA October 1997

15. Orr, Michael J. (16 September 2010). An Unholy Alliance. iUniverse. p. 78. ISBN 978-1-4502-5403-8. Retrieved 1 October 2011.

16. International Journal of Innovative Research in Science, Engineering and Technology Vol. 2, Issue 7, July 2013 Copyright to IJIRSET www.ijirset.com 2992 REVIEW OF HEAVY METALS IN DRINKING WATER AND THEIR EFFECT ON HUMAN HEALTH

17. Sardar Khana,b, ${ }^{*}$,Maria Shahnaz a,Noor Jahana,Shafiqur Rehmana,M.Tahir Shahc,Islamud Dind Journal of cleaner Production xxx (2012)1- 9.

18. N.H-Zarel, N. Saadati 1,H.Hassonizade1,P.Barati1,M.Ahmadi 1,Z.Nazari2.1.Water,Soil \&Sediment Laboratory of Khouzestan Water \&Power Authority;2.Department of Toxicology \&Pharmacology, Pharmacy School,Ahvaz Jondishapour, University of medical Sciences(2003-2007)

19. Guidelines for drinking-water quality, 2nd ed. Addendum to Vol. 2. Health criteria and other supporting information. World Health Organization, Geneva, 1998.

20. Cadmium in Drinking-water Background document for development of WHO Guidelines for Drinkingwater Quality

21. Friberg L, Nordberg GF, Vouk VB, eds. (1986) Handbook of the toxicology of metals. Vol. II. Amsterdam, Elsevier, pp. 130-184.

22. Environmental Health Perspectives * VOLUME 1081 NUMBER 81 August 2000

23. WHO Lead. Environmental Health Criteria, Geneva, 165, (1995).

24. Council Directive 98/83/EC/1998 Quality of Drinking Water.

25. Document for Public Consultation Prepared by the Federal-Provincial-Territorial Committee on Drinking Water Consultation period ends September 23, 2015

26. Chem Sci Trans., 2012, 1(3), 669-673 